\section{Characterization of New Sources of Resistance in Cowpea to the Southern Root-knot Nematode}

\author{
Richard L. Fery', Philip D. Dukes ${ }^{2}$, and Judy A. Thies ${ }^{2}$ \\ U.S. Vegetable Laboratory, Agricultural Research Service, U.S. Department \\ of Agriculture, 2875 Savannah Highway, Charleston, SC 29414-5334
}

Additional index words. southernpea, blackeye bean, Vigna unguiculatu, Meloidogyne incognita, vegetable breeding, genetics, allelism test

\begin{abstract}
A series of greenhouse and field studies was conducted over 9 years to characterize three new sources of resistance in cowpea [Vigna unguiculata (L.) Walp.] to the southern root-knot nematode [Meloidogyne incognita (Kofoid \& White) Chitwood] and to determine if the resistances are conditioned by genes allelic to the $R \boldsymbol{k}$ root-knot nematode resistance gene in 'Mississippi Silver'. Three plant introductions (PI), PI 441917, PI 441920, and PI 468104, were evaluated for reaction to $M$. incognita in four greenhouse tests, and in every test each PI exhibited less galling, egg mass formation, or egg production than 'Mississippi Silver'. $F_{2}$ populations of the crosses between 'Mississippi Silver' and each of the three resistant PIs were also evaluated for root-knot nematode resistance in a greenhouse test. None of the $\mathrm{F}_{2}$ populations segregated for resistance, indicating that PI 441917, PI 441920, and PI 468104 each has a gene conditioning resistance that is allelic to the $R \boldsymbol{k}$ gene in 'Mississippi Silver'. Our observations on the superior levels of resistances exhibited by PI 441917, PI 441920, and PI 468104 suggest that the allele at the $R k$ locus in these lines may not be the $R k$ allele, but one or more alleles that condition a superior, dominant-type resistance. The availability of additional dominant alleles would broaden the genetic base for root-knot nematode resistance in cowpea.
\end{abstract}

Root knot, a disease incited by several species of the root-knot nematode genus Meloidogyne, is one of the major diseases of cowpea. The southern root-knot nematode is the predominant species pathogenic on cowpea worldwide. A recent review of the literature suggests that a single dominant gene of cowpea conditions a general-type resistance to several Meloidogyne species (Fery, 1985). Fery and Dukes (1980), for example, showed that the dominant resistance genes in 'Colossus', 'Iron', and PI 353383 are all allelic to the dominant $R k$ root-knot nematode resistance gene in 'Mississippi Silver', and that the $R k$ gene conditions a high level of resistance to not only the southern root-knot nematode, but also the tropical root-knot nematode $[M$. javanica (Treub.) Chitwood] and the northern root-knot nematode (M. hapla Chitwood). They noted that races are known to exist within two Meloidogyne spp. (Sasser, 1980) and raised the question of genetic vulnerability of cowpea to root-knot nematodes. Fery and Dukes (1980) suggested that a search of cowpea germplasm should be initiated to identify other root-knot nematode resistance genes.

In 1984, researchers at the U.S. Dept. of Agriculture's Regional Plant Introduction Sta-

Receivedforpublication12July 1993, Accepted for publication 17 Oct. 1993. We acknowledge the assistance of F.P. Maguire, R.B. Cuthbert, II, and E.L. Corley, Jr., agricultural research technicians. The cost of publishing this paper was defrayed in part by the payment of page charges. Under postal regulations, this paper therefore must be hereby marked advertisement solely to indicate this fact.

${ }^{1}$ Research Geneticist.

${ }^{2}$ Research Plant Pathologist, tion, Griffin, Ga., initiated a program to evaluate the U.S. Cowpea Germplasm Collection for reaction to $M$. incognita (C. Adamson, personal communication). Although the entire collection was not screened, PI 441917, PI 441920, and PI 468104 were found to exhibit exceptionally high degrees of resistance to root-knot nematode (C. Adamson, unpublished data). Our paper reports the results of a series of studies carried out to characterize the resis(PI) and to determine if the resistances are conditioned by genes allelic to the $R k$ resistance gene in 'Mississippi Silver'.

\section{General Materials and Methods}

The data reported here are from greenhouse and field experiments conducted at the U.S. Vegetable Laboratory, Charleston, S.C. All evaluations for reaction to $M$. incognita were conducted in the greenhouse using $4.1 \times$ $1.7 \times 0.2-\mathrm{m}$ benches containing a steam-sterilized mixture of $\approx 6$ soil :3 sand : 1 peat (by volume). Egg inocula were extracted from cowpea or pepper (Capsicum annuum L.) roots infected with $M$. incognita using the sodium hypochlorite procedure described by Hussey and Barker (1973). Meloidogyne incognita Race 3 was used in all tests conducted from 1985 through 1990; a 1:1 mixture of Races 1 and 3 (predominant races) was used in the 1993 test (Sasser, 1980). At planting, single cowpea seeds were dropped into 2-cm-deep holes and inoculated with an aliquant of water containing freshly extracted eggs. The planting arrangement was a $10 \times 12-\mathrm{cm}$ rectangular pattern. The outermost two rows on the perimtances exhibited by these plant introductions eter of each bench were used as buffers to minimize the effects of moisture and temperature stresses. 'Mississippi Silver' was used as the resistant control and 'Pinkeye Purple Hull' (PEPH) as a conservative susceptible control in all tests. PEPH is considered a conservative control because it is homozygous for a recessive gene $\left(r k^{i}\right)$ conditioning an intermediate type of resistance (Fery and Dukes, 1982). Greenhouse air temperatures were maintained between 24 and $35 \mathrm{C}$.

Subjective scores were used to evaluate plants for prevalence of root galling and egg masses. The scale for severity of galling was 1 $=$ no galls; $2=$ slight galling; 3 = light galling; 4 = light to moderate galling; $5=$ moderate galling; $6=$ moderate to heavy galling; $7=$ heavy galling; and $8=$ severe galling. The number of egg masses per root system was rated as follows: 1 = no egg masses evident; 2 = rare occurrence of egg masses; $3=$ occasional occurrence of egg masses; $4=$ occasional to moderate occurrence of egg masses; $5=$ moderate frequency of egg masses; $6=$ moderate to numerous frequency of egg masses; 7 = numerous egg masses; and $8=$ extremely high frequency of egg masses. All plants with gall and egg mass indices $\leq 3$ were classified as root-knot nematode resistant; plants with gall or egg mass indices $\geq 4$ were classified as susceptible.

\section{Specific Methods and Results}

The initial evaluation of PI 441917, PI 441920, and PI 468104 for reaction to $M$. incognita was a nonreplicated greenhouse test. Ten seeds per accession were planted, and each seed was inoculated with $\approx 3200 \mathrm{M}$. incognita eggs. The test was planted on 15 Aug. 1985 , and the roots were evaluated for gall formation on 10 Oct. 1985. Gall formation on the control cultivars was as expected (Table 1). Roots of the 'Mississippi Silver' plants exhibited slight galling, while the roots of PEPH were moderately galled. Roots of PI 441917 plants exhibited the highest level of resistance to $M$. incognita that we have observed in an inoculated cowpea test; no obvious gall formation occurred on the roots of any of the test plants. The PI 441920 population segregated for resistance; all susceptible plants exhibited severe galling (gall index $=8.00 \pm$ 0.00 ), but the resistant plants showed only slight galling, and the resistance appeared to be superior to that of 'Mississippi Silver'. All PI 468104 plants were resistant; the level of resistance was similar to that of the resistant PI 441920 plants.

Remnant seed of PI 441917, PI 441920, and PI 468104 were planted in a 1987 field planting, and selfed seeds were harvested from single plants. Individual plants from this planting were progeny-tested for root-knot nematode resistance in a nonreplicated greenhouse test in 1988. Twenty seeds from each of five progeny populations from each PI were planted, and each seed was inoculated with $\approx 2500$ eggs at the time of planting. The test was planted on 9 Mar. 1988, and the roots were evaluated for gall and egg mass formation on 8 June 1988. 
Table 1. Response of parental and $\mathrm{F}_{2}$ populations of the crosses PI 441917 × 'Mississippi Silver', PI 441920 × 'Mississippi Silver', and PI 468104 x 'Mississippi Silver' to the southern root-knot nematode (Meloidogyne incognita) and egg production by the nematode on roots of the parental lines.

\begin{tabular}{|c|c|c|c|c|c|c|c|c|}
\hline \multirow[b]{2}{*}{ Population } & \multicolumn{4}{|c|}{ Gall index ${ }^{2}$} & \multicolumn{3}{|c|}{ Egg mass index } & \multirow{2}{*}{$\begin{array}{c}\text { No. eggs/ } \\
\text { mg root tissue } \\
(1993)\end{array}$} \\
\hline & 1985 & 1988 & 1990 & 1993 & 1988 & 1990 & 1993 & \\
\hline \multicolumn{9}{|l|}{ Parents $^{x}$} \\
\hline PI 441917 & $1.0 \pm 0.00^{\mathrm{w}}$ & $1.7 \pm 0.10$ & $1.9 \pm 0.11$ & $1.5 \pm 0.08$ & $1.1 \pm 0.05$ & $1.3 \pm 0.11$ & $1.5 \pm 0.08$ & $5.72 \pm 0.11$ \\
\hline PI 441920 & $1.8 \pm 0.17^{\vee}$ & $2.0 \pm 0.00$ & $2.2 \pm 0.09$ & $2.0 \pm 0.02$ & $1.2 \pm 0.12$ & $1.3 \pm 0.11$ & $2.0 \pm 0.02$ & $7.63 \pm 2.30$ \\
\hline PI 468104 & $1.9 \pm 0.12$ & $1.9 \pm 0.05$ & $2.0 \pm 0.05$ & $1.2 \pm 0.07$ & $1.3 \pm 0.11$ & $1.1 \pm 0.07$ & $1.0 \pm 0.04$ & $0.07 \pm 0.07$ \\
\hline M. Silver (MS) & $2.1 \pm 0.12$ & $1.8 \pm 0.10$ & $2.3 \pm 0.10$ & $2.0 \pm 0.03$ & $2.0 \pm 0.20$ & $2.0 \pm 0.00$ & $2.0 \pm 0.03$ & $6.20 \pm 1.09$ \\
\hline \multicolumn{9}{|l|}{$F_{2}$ populations ${ }^{u}$} \\
\hline PI $441917 \times$ MS & --- & --- & $2.0 \pm 0.03$ & --- & --- & $1.3 \pm 0.04$ & --- & --- \\
\hline PI $441920 \times \mathrm{MS}$ & .-- & -.- & $2.0 \pm 0.05$ & --- & --- & $1.2 \pm 0.04$ & --- & --- \\
\hline PI $468104 \times$ MS & --- & --- & $1.9 \pm 0.04$ & --- & --- & $1.2 \pm 0.04$ & --- & --- \\
\hline \multicolumn{9}{|l|}{ Control } \\
\hline PEPH' & $5.0 \pm 0.13$ & $4.7 \pm 0.17$ & $5.1 \pm 0.10$ & $5.8 \pm 0.15$ & $5.3 \pm 0.13$ & $5.7 \pm 0.11$ & $5.1 \pm 0.08$ & $54.44 \pm 7.84$ \\
\hline
\end{tabular}

Plants rated on a scale of 1 to $8 ; 1=$ no galling and $8=$ severe galling.

Plants rated on a scale of 1 to $8 ; 1=$ no egg masses and $8=$ large number of egg masses.

${ }^{\times} 1988,1990$, and 1993 data taken on plants of homozygous resistant lines selected from PI 441917. PI 441920, and PI 468104. The experimental designations of the lines selected from PI 441917, PI 441920, and PI 468104 were US-567, US-566, and US-568, respectively; the selected lines were used to make needed crosses. " \pm standard error.

'Mean of resistant plants (PI 441920 segregated for resistance); the mean gall index for the four susceptible plants was 8.0+ 0.()().

"None of the $\mathrm{F}_{2}$ populations segregated for resistance

'Pinkeye Purple Hull' (susceptible control).

The results of this test confirmed that PI441920 is segregating for resistance and that PI441917 and P1468104 are homozygous resistant. Most of the plants in the resistant progeny populations exhibited the slight galling response typical of 'Mississippi Silver', but not the slight egg mass formation that is also typical of 'Mississippi Silver'.

In 1989, a homozygous-resistant progeny population from each PI was used to make a cross with 'Mississippi Silver', and each F, was subsequently advanced to the $\mathrm{F}_{2}$ generation. In 1990, the parental and $F_{2}$ populations of these crosses were evaluated for root-knot nematode resistance in a replicated greenhouse test. Five seeds of each parental population and 30 seeds of each $\mathrm{F}_{2}$ population were planted in each of four replications, and each seed was inoculated with $\approx 2480 \mathrm{M}$. incognita eggs at the time of planting. The test was planted on 10 Jan. 1990, and the roots were evaluated for gall and egg mass formation on 30 Mar. 1990. Again, most of the plants in the resistant parental populations exhibited the slight galling response typical of 'Mississippi Silver', but not the slight egg mass formation that is also typical of 'Mississippi Silver'. None of the $\mathrm{F}_{2}$ populations segregated for resistance, indicating that each of the PIs has a gene conditioning resistance to $M$. incognita that is allelic to $R k$, the root-knot nematode resistance gene in 'Mississippi Silver'. Each $\mathrm{F}_{2}$ population exhibited the galling and egg mass response typical of its resistant PI parent.

The ability of $M$. incognita to reproduce on
PI 441917, PI 441920, and PI 468105 plants was evaluated in a 1993 test. Five seeds of each accession were planted in each of four replications, and each seed was inoculated with $\approx 2960 \mathrm{M}$. incognita eggs at the time of planting. The test was planted on 2 Mar. 1993, and the roots were evaluated on 27 Apr. 1993. The procedure developed by Hussey and Barker ( 1973) was used to extract eggs from the total root tissue collected from each plot. Meloidogyne incognita egg production on PI 441917 and PI 441920 roots was similar to the level exhibited by the resistant control, 'Mississippi Silver'. However, egg production on the roots of PI 468104 plants was only $1.1 \%$ of the number produced on the roots of 'Mississippi Silver'. In this test, the plants in the PI 441917 and PI 468104 populations exhibited less gall and egg mass formation than 'Mississippi Silver' plants, but the responses of PI 441920 plants were similar to those characteristic of 'Mississippi Silver' plants.

\section{Discussion}

The results of these studies confirm $\mathrm{C}$. Adamson's observations (unpublished data) that PI 441917, PI 441920, and PI 468104 exhibit exceptionally high levels of resistance to root-knot nematode. In every greenhouse test in which the seed were inoculated with $M$. incognita eggs, each PI either exhibited a lower gall, egg mass, or egg production response than 'Mississippi Silver'. The results of the allelism tests indicate that the gene conditioning the resistance in each PI is located on the same locus as the $R k$ gene. However, our observations on the levels of resistances exhibited byPI 441917, PI 441920, and PI 468104 suggest that the allele at the $R k$ locus in each of these lines might not be the $R k$ allele, but another allele that conditions a superior, dominant-type resistance. The availability of additional dominant resistance alleles at the $R k$ locus would broaden the genetic base for root-knot nematode resistance in cowpea. PI 441917, PI 441920, and PI 468104 should be included in any cowpea germplasm collection being evaluated for resistance to any new race of a Meloidogyne spp. that breaks the general resistance conditioned by the $R k$ allele.

\section{Literature Cited}

Fery, R.L. 1985. The genetics of cowpeas: A review of the world literature, p. 25-62. In: S.R. Singh and K.O. Rachie (eds.). Cowpea research, production and utilization. Wiley, London.

Fery, R.L. and P.D. Dukes. 1980. Inheritance of root-knot resistance in the cowpea [Vigna unguiculata (L.) Walp.]. J. Amer. Soc. Hort. Sci. 105:671-674.

Fery, R.L. and P.D. Dukes, 1982. Inheritance and assessment of a second root-knot resistance factor in southernpea [Vigna unguiculata (L.) Walp.]. HortScience 17:152. (Abstr.)

Hussey, R.S. and K.R. Barker. 1973. A comparison of methods of collecting inocula of Meloidogyne spp., including a new technique. plant Dis. Rptr. 57:1025-1028.

Sasser, J.N. 1980. Root-knot nematodes: A global menace to crop production. Plant Dis. 64:36-41. 